\title{
Purification and Characterization of the Lipase from Marine Vibrio fischeri
}

\author{
P. Ranjitha (Corresponding author) \\ Research Department of Microbiology, Sengunthar Arts and Science College \\ Tiruchengode 637 205, Tamilnadu, India \\ E-mail: ranjithaponn@gmail.com \\ E. S. Karthy \\ Research Department of Microbiology, Sengunthar Arts and Science College \\ Tiruchengode 637 205, Tamilnadu, India
}

A. Mohankumar

Research Department of Microbiology, Sengunthar Arts and Science College

Tiruchengode 637 205, Tamilnadu, India

\begin{abstract}
Lipolytic enzymes from marine microbes have been the focus of intense and growing research. The bioluminescence bacterium Vibrio fischeri was produced lipase enzyme when the medium contained specific substrate. The lipase was purified from the concentrated culture supernatant. The most active fractions were obtained using the technique of precipitation with ammonium sulphate. The precipitated fraction was purified by desalting and ion exchange chromatography. The purified active fraction exhibiting final specific activity of $121 \mathrm{U} / \mathrm{mg}$ and characterized; the optimum $\mathrm{pH}$ was likely between 7 to 8 , the optimum temperature was $30^{\circ} \mathrm{C}$ and about $80 \%$ of activity at $5^{\circ} \mathrm{C}$. The enzyme was very stable at the $\mathrm{pH} 8$, at the temperature $30^{\circ} \mathrm{C}$. The enzyme was monomeric protein having molecular mass of $57 \mathrm{KDa}$ estimated by native PAGE assay.
\end{abstract}

Keywords: Vibrio fischeri, Lipolytic enzymes, Extracellular, Lipase

\section{Introduction}

Marine microorganisms which are salt tolerant, provide an interesting alternative for therapeutic purposes. Marine microorganisms have a diverse range of enzymatic activity and are capable of catalyzing various biochemical reactions with novel enzymes. Especially, halophilic microorganisms possess many hydrolytic enzymes and are capable of functioning under conditions that lead to precipitation of denaturation of most proteins. Further it is believed that sea water, which is saline in nature and chemically closer to the human blood plasma, could provide microbial products, in particular the enzymes, that could be safer having no or less toxicity or side effects when used for therapeutic applications to humans (Sabu, 2003).

The Photobacterium (Vibrio) fischeri group consists of rod-shaped cells with a light yellow, cell-associated pigment and a tuft of sheathed flagella (Hendrie et al., 1970). The species is restricted to the marine environment and has a specific requirement for sodium ion for growth (Reichelt and Baumann, 1973). It occurs both free living in sea water (Ruby and Nealson, 1976) and as the specific luminous symbiont of the monocentrid fish and squid.

Lipases, triacylglycerol hydrolases, catalyse both the hydrolysis and synthesis of esters formed from glycerol and long chain fatty acids. These enzymes exhibit broad substrate specificity and degrade tweens, phospholipids often with positional, stereo and chain length selectivity (Jaeger et al., 1994). Lipases have been recognized as very useful biocatalysts because of their wide ranging versatility in industrial applications such as food technology, detergent, 
chemical industry and biomedical sciences (Jaeger and Reetz, 1998; Jaeger et al., 1999; Ghanem et al., 2000; Gupta et al., 2004). Information of lipolytic enzymes produced by marine Vibrio spp is particularly limited. Therefore, the objective of this study is to focus on the lipase production of $V$. fischeri isolated from squid and on the purification and partial characterization of its lipase.

\section{Experiments}

\subsection{Bacteria and growth conditions}

The squids (Sepia sp.) were collected and cooled to about $8^{\circ} \mathrm{C}$ before opening the mantle cavity along the ventrum. The following two methods were used to obtain samples of symbiotic luminescent bacteria. Light organ fluid containing bacteria was obtained from pore that leads into channels with in the organ tissue. Whole light organs were removed by dissection and homogenized in $700 \mu 1$ of sterile seawater (Ruby and Nagai, 1992). Material obtained in either of these ways was serially diluted in seawater complete (SWC) broth and the samples were spreaded on $\mathrm{SWC}(0.38 \mathrm{M} \mathrm{NaCl}$, $0.02 \mathrm{M} \mathrm{MgCl}_{2} \cdot 6 \mathrm{H}_{2} \mathrm{O}, 0.025 \mathrm{M} \mathrm{MgSO}_{4} \cdot 7 \mathrm{H}_{2} \mathrm{O}, 8 \mathrm{mM} \mathrm{KCl}, 0.5 \%$ peptone, $0.3 \%$ yeast extract, $2 \%$ agar and $0.3 \%$ glycerol) agar plates and identified the luminous bacteria based on the work of Reichelt and Baumann (1973) and VHA (Vibrio Hareyi Agar) differential media (Harris et al., 1996).

\subsection{Screening of Lipase Enzyme}

\subsubsection{ZoBell 2216E modified media}

All strains were precultivated on the solid maintenance SWC medium. For detection of lipolytic activity the following basal medium (Zobell 2216E, slightly modified) was used. It contains $10 \mathrm{~g}$ of peptone, $1 \mathrm{~g}$ of yeast extract, $0.05 \mathrm{~g}$ of $\mathrm{CaCl}_{2}, 15 \mathrm{~g}$ of bacto agar made to $1 \mathrm{~L}$ with aged seawater, $\mathrm{pH}$ was adjusted to 7.6. The media supplements with either of $1 \%$ tweens $(20,80)$ or $0.25 \%$ Triacylglycerols (tributyrin, triolein) were then poured into petri disches, after solidification of these media inoculated and incubated at $30^{\circ} \mathrm{C}$ for 10 days. The total diameter, minus the diameter of the colony was considered to be proportional to the lipolytic activity rate. After 1-10 day incubation the halos, clear (on tributyrin, triolein) or turbid (on all other substrates) were measured.

\subsubsection{Spirit Blue Agar}

Broth culture was streaked on the spirit blue agar plates with substrate (Tweens or Triacylglycerol). Then the plates were incubated at different temperature $6^{\circ} \mathrm{C}, 17^{\circ} \mathrm{C}, 30^{\circ} \mathrm{C}$ for up to 15 days. The plates were observed after $6 \mathrm{hrs}$ and every 12 hrs for the clearing of the blue or deep blue color around each streak. Lipolytic activities at different hours were compared by measuring the width (millimeter) of areas of cleaning or area of deep blue color around the colonies.

\subsubsection{Rhodamine B Agar}

A plate assay to detect bacterial lipase in a medium containing olive oil or triglycerol and the florescent dye rhodamine B. Growth medium was adjusted to $\mathrm{pH} 7.0$, autoclaved and cooled about $60^{\circ} \mathrm{C}$. Then $1 \%$ of olive oil, $10 \mathrm{ml}$ of rhodamine B solution $(0.001 \% \mathrm{w} / \mathrm{v})$ was added with vigorous stirring and emulsified by mixing for 1 min with an homogenizer. $20 \mathrm{ml}$ of medium was poured into each petri dish. The overnight culture was spotted in the centre of the plate and incubated for $48 \mathrm{hrs}$. The plates were incubated for $16 \mathrm{hrs}$ at $30^{\circ} \mathrm{C}$. Lipase production was monitored by irradiating plates with UV light at $350 \mathrm{~nm}$. After $16 \mathrm{hrs}$ of incubation bacterial colonies began to show an orange fluorescence, with continuing incubation time orange fluorescent halos were formed around the colonies.

\subsection{Enzyme Production and Preparation of Cell Free Filtrate}

$150 \mu \mathrm{l}$ of culture was inoculated into $200 \mathrm{ml}$ of sea water medium with substrate and incubated at $30^{\circ} \mathrm{C}$ for 3 days. The portion was centrifuged at $20,000 \mathrm{xg}$ at $4^{\circ} \mathrm{C}$ for $30 \mathrm{~min}$. The supernatant was filtered using $0.45 \mu \mathrm{m}$ cellulose acetate filter units. The cell free filtrate was used as the crude enzyme in the purification experiments.

\subsection{Purification of extracellular lipase}

\subsubsection{Ammonium Sulfate Fractionation and Dialysis Against Buffer (Desalting)}

Solid ammonium sulphate was added to the fraction 1 at $20 \%$ saturation and allowed to stand for $30 \mathrm{~min}$. The precipitate obtained was separated by centrifugation (Fraction II) and the resulting supernatant was further treated with solid ammonium sulphate at $40 \%$ saturation. The precipitate obtained was collected by centrifugation (Fraction III). The supernatant was similarly treated with ammonium sulphate at 60 and $80 \%$ saturation and the precipitates obtained were termed as fractions IV, V respectively. All the precipitates (II-V) were resuspended in a minimal amount of buffer $(0.1 \mathrm{M}$ Tris-HCl, $\mathrm{pH}$ 7.0) and dialyzed against the same buffer by using successive large volume of buffer. The process was continued till the last trace of ammonium sulphate was removed. The desalted fractions were used for further process. All the concentrated fractions (II-V) were subjected to protein and enzyme activity assay to choose the fraction containing maximum activity. 


\subsubsection{Ion-exchange chromatography (DEAE-Cellulose Column)}

The dialyzed sample was removed from the tubing and filtered through a $0.45 \mu \mathrm{m}$ filter. Then applied to a column previously equilibrated with $0.01 \mathrm{M}$ Tris $\mathrm{HCl}$ buffer $(\mathrm{pH}$ 7.2) slowly percolating large volume of buffer through packed material. A sample of desalted enzyme preparation was loaded onto the column. The elution of the pure lipolytic enzyme accomplished with 15 column volume gradient of $\mathrm{NaCl}$ obtained by $270 \mathrm{ml}$ of $0.6 \mathrm{M} \mathrm{NaCl}$ in $0.01 \mathrm{M} \mathrm{Tris} \mathrm{HCl}$ buffer (pH 7.2). Flow rate was controlled at $0.5 \mathrm{ml} / \mathrm{min}$ by $5 \mathrm{ml}$ of fractions collected and analyzed for protein and enzyme activity. After assaying the fractions for lipase activity, fractions collected from DEAE-cellulose chromatography were impregnated on to a small disc $(5 \mathrm{~mm})$ of filter paper and placed on top of chromogenic substrate plates. The plates were incubated at $30^{\circ} \mathrm{C}$ for $15-30 \mathrm{~min}$. Those with highest activity were pooled together and used for further enzyme characterization.

\subsection{Enzyme Activity Assay}

Enzyme assay used for the determination of lipase activity upon emulsified substrates and Tween solutions. The final concentration of oil was $10 \%$, gum arabic $8 \%$, Triacylglycerols (TAGs) $10-50 \mathrm{mM}$, Tweens $0.8-20 \%$ (v/v). The mixture of the substrate and buffer (final volume $8 \mathrm{ml}$ ) was adjusted to $\mathrm{pH} 8.0$ by $1 \mathrm{~N} \mathrm{NaOH}$ and the $\mathrm{pH}$ was maintained for 3 min by titration with $50 \mathrm{mM} \mathrm{NaOH}$ solution (blank). Then $1 \mathrm{ml}$ of the lipase solution in the buffer was added and the lipolytic reaction was observed for $40 \mathrm{~min}$ by titration as mentioned above. Enzyme activity is expressed as U/ml and one unit (U) of activity is defined as $\mu$ mols of free fatty acids liberated $/ \mathrm{min} / \mathrm{ml}$ by the enzyme solution under assay conditions.

\subsection{Protein Mass Determination (Native PAGE)}

In order to study the undenatured protein profile of lipase enzyme from $V$. fischeri in cell free broth, performed electrophoresis by the method described by Lammeli et al., (1970) with some modifications (Vorderwulbecke et al., 1992). Gel was casted by using discontinuous buffer system having $10 \%$ resolving gel and 5\% stacking gel. For measurement of molecular mass of protein, commercial broad range molecular mass standard proteins were used. Protein bands were located by coomassie blue staining and molecular mass was determined using TotalLab v2.01 software.

\subsection{Characterization of Lipase Enzyme}

\subsection{1 pH stability}

Enzyme solutions at a concentration of $70 \mathrm{mg} / \mathrm{ml}$ were adjusted to various $\mathrm{pH}$ ranging from $\mathrm{pH} 2$ to 11 with either $0.1 \mathrm{~N}$ $\mathrm{NaOH}$ or $0.1 \mathrm{~N} \mathrm{HCl}$ and aliquots were incubated at $30^{\circ} \mathrm{C}$ for $4 \mathrm{hrs}$. Then aliquot was removed and assayed for activity.

\subsection{2 $\mathrm{pH}$ optimum}

Enzyme assays were conducted at various $\mathrm{pH}$ in an emulsified reaction mixture containing $0.4 \mathrm{ml}$ of oil or Tween or TAG, $4 \mathrm{ml} 50 \mathrm{mM}$ Tris, $0.1 \mathrm{ml}$ enzyme. The $\mathrm{pH}$ was maintained by $\mathrm{pH}$ stat with $0.02 \mathrm{NaOH}$. After incubation of the reaction mixture for $40 \mathrm{~min}$ at $30^{\circ} \mathrm{C}$, it was titrated to $\mathrm{pH}$. The quantity of free fatty acids released was calculated from the total quantity of base used. Control reaction mixture contained heat inactivated enzyme.

\subsubsection{Temperature stability}

The solution of enzyme at concentration of $45 \mathrm{mg} / \mathrm{ml}$ was adjusted to $\mathrm{pH} 7.0$ with $0.02 \mathrm{NaOH}$ and aliquots were incubated at temperatures ranging from $5^{\circ} \mathrm{C}$ to $65^{\circ} \mathrm{C}$ for $4 \mathrm{hrs}$. Then the aliquots were assayed for activity.

\subsubsection{Temperature optimum}

Enzyme activity was determined at various temperatures ranging from $5^{\circ} \mathrm{C}$ to $65^{\circ} \mathrm{C}$. The reaction mixtures (except enzyme) were held at the respective temperature for $5 \mathrm{~min}$ before the addition of the enzyme.

\subsubsection{Substrate and Enzyme Kinetics}

The lipase enzyme was incubated with various concentrations of substrates and the final substrate concentration ranged from 1 to $10 \mathrm{mM}$ of tributyrin, triolein. Different concentrations of enzymes also studied in the concentration of 5, 10, 15 and 20 microlitres.

\subsubsection{Enzyme Stability on metal ions and other chemicals}

Enzymes were preincubated for $1 \mathrm{~h}$ at $30^{\circ} \mathrm{C}(\mathrm{pH} 7.0)$ and in $0.1 \mathrm{M}$ Tris- $\mathrm{HCl}$ buffer with various ions and other chemicals (one at a time). Assay was performed with the mixture, which did not contain $\mathrm{CaCl}_{2}$ (except in test sample). The ions used were included $\mathrm{NaCl}(10 \mathrm{mM}), \mathrm{BaCl}_{2}(0.001 \mathrm{M}), \mathrm{MgCl}_{2}(0.001 \mathrm{M}), \mathrm{KCl}(2 \mathrm{mM}), \mathrm{FeSO}_{4}(0.001 \mathrm{M}), \mathrm{CaCl}{ }_{2}(0.001 \mathrm{M})$, $\mathrm{SrCl}_{2}(0.001 \mathrm{M}), \mathrm{NaF}(2 \mathrm{mM}), \mathrm{MnCl}_{2}(2 \mathrm{mM}), \mathrm{CuO}_{2}(2 \mathrm{mM})$. Other chemicals tested were ethylene diamine tetra acetic acid $(0.5 \%$ EDTA), the ammonic detergent, sodium dodecyl sulphate $(0.5 \%$ SDS). 


\subsubsection{Enzyme Stability During Storage}

Enzyme solutions from 2 days culture were stored at $-20,1,8$, and $20^{\circ} \mathrm{C}$. Formaldihyde was added to a final concentration of $0.04 \%$ to prevent bacterial growth. $30 \mathrm{ml}$ of a 2 days culture of lipase solution was sterilized by membrane filtration $(0.22 \mu \mathrm{m}$, Millipore corp.,). The lipase activity in the stored samples was determined periodically by the $\mathrm{pH}$ stat technique and expressed as percent initial activity.

\section{Results and Discussion}

\subsection{Bacteria and growth condition}

V. fischeri encountered $100 \%$ of luminous bacteria. Total viable luminous count range was varied from 4 to $18 \mathrm{CFU} / \mathrm{ml}$. The habitats of this squid species must receive a significant input of cells of symbiotic $V$. fischeri (Lee and Ruby, 1994). The luminous $V$. fischeri isolate was motile Gram negative rods. They produced yellow colonies on SWC agar plates. They were halophiles, unable to grow in the absence of $\mathrm{NaCl}$. The colony morphology of the luminous $V$. fischeri strains tested on VHA was small (2 to 5mm) dark blue green colonies. Harris et al., (1996) reported that the VHA media displays great potential as primary isolation medium and offers significant advantages over thiosulfate-citrate- bile salts- sucrose agar.

\subsection{Screening of Lipase Enzyme}

In ZoBell modified media, the $V$. fischeri was showed $40 \mathrm{~mm}$ of halos after 10 days incubation indicates that the strain $V$. fischeri showed significant lipase activity. In fact it actively splits tributyrin and tween 80 than triolein as good substrates. Bruni et al., (1982) reported that the most strains of Pseudomonas sp. NCMB 1082 was split all tweens, tributyrin, but not triolein, 9 strains showed good activity on water soluble tweens, 4 on tween 85 . In spirit blue agar, the width of hydrolysis areas were measured to observe the lipase activity of luminous $V$. fischeri bacteria at different temperatures. At $30^{\circ} \mathrm{C}$, the lipase activity of strain was appeared after $7 \mathrm{hrs}$ with a large discoloration area or dark blue halos and the widest area observed after 1 day. At $17^{\circ} \mathrm{C}$, the activity began after $12 \mathrm{hrs}$, the size of halos increase after 3 days but the area of hydrolysis was smaller than that at $30^{\circ} \mathrm{C}$. Apparently low activity was observed at $6^{\circ} \mathrm{C}$. More or less similar $\mathrm{mm}$ of halos as that in ZoBell modified agar was observed in spirit blue agar with the substrate (tweens, triacylglycerol) at $30^{\circ} \mathrm{C}$. The higher activity at $30^{\circ} \mathrm{C}$ may be attributed to maximum growth of the organism and subsequently increased lipase secretion. Similar results were observed by Makhzoum et al., (1995) during their study of lipase production by $P$. fluorescens. In Rhodamine B agar, the strains of $V$. fischeri showed $12 \mathrm{~mm}$ of orange halos around the bacterial colonies at the 10 day incubation. Kouker and Jaeger (1987) detected a plate assay for bacterial lipase in a medium containing triacylglycerol and the fluorescent dye rhodamine B. Substrate hydrolyses causes the formation of orange fluorescence halos around bacterial colonies visible upon UV irradiation.

\subsection{Purification of Lipase Enzyme}

Highest yield was obtained in the medium after 3 days at $30^{\circ} \mathrm{C}$. To minimize the loss of enzyme activity, the purification procedures were performed at $4^{\circ} \mathrm{C}$. Results of several trials indicated that $60 \%$ saturation of the supernatant fluid with ammonium sulfate precipitated the largest amount of lipase. After dialysis, the specific activity of lipase containing dialysate was increased than that in culture supernatant fluid. In DEAE - cellulose chromatography, lipolytic

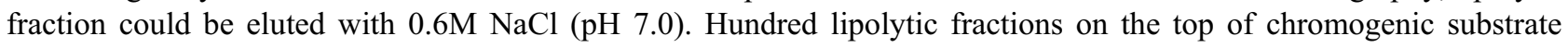
plates showed yellow zone around the disc, those highest activity was observed in between the fractions of 40-46, similar result was observed in titrimetric assay. DEAE-cellulose column chromatogram is shown in Figure 5. The purified lipase was exhibiting final specific activity of $121 \mathrm{U} / \mathrm{mg}$ and also showed single band in native PAGE. Nawani and Kaur (2000) have been used phenyl sepharose chromatography as a single step process that yielded a high active and pure lipase. Low yield of purified enzymes can be attributed to loss during ammonium sulphate precipitation as well as tight binding of lipase to hydrophobic column as a significant amount of lipase activity never eluted from the column. Like most of Bacillus lipases, the lipase from Bacillus J33 does not form aggregates (Lesuisse et al., 1993; Schmidt-Dannert et al., 1994). On the CM-cellulose column, the highest lipase activity was eluted very early in fractions 6 to 20 and about $93 \%$ of its activity was recovered. Active fractions were applied to the DEAE-cellulose and the lipase activity was highest between 0.23 and $0.35 \mathrm{M} \mathrm{NaCl}$ in fractions 21 to 32 and the recovery was $45 \%$. The purified lipase showed only one protein band on SDS-PAGE (Abdou, 2003).

\subsection{Molecular Mass}

The lipase from $V$. fischeri was showed molecular mass of $57 \mathrm{KDa}$ was calculated by $\mathrm{Rf}$ value. The crude lipase (culture supernatant) was showed multiprotein bands, indicates the impurities of other proteins (Fig 6). Lipases from $P$. flurescens had a molecular mass of 55, 52, $32 \mathrm{KDa}$ (Bazoglu, 1984; Kumura et al., 1993; Stepaniak and Fox, 1985). The lipase molecular mass was estimated to be $52 \mathrm{KDa}$ (Abdou, 2003). Matsumae and Shibatani (1994) found that the molecular mass for $S$. marcescens lipase was $62 \mathrm{KDa}$, while that of $S$. grimisii was $57 \mathrm{KDa}$ (Abdou, 1997). The lipase from a bacterium (Pseudomonas aeruginosa YS-7) showed the molecular size of $40 \mathrm{KDa}$ hydrolysed a variety of fatty acid esters (Shabtai and Mishne, 1992). 


\subsection{Characterization of Lipase}

\subsection{1 pH stability}

The purified lipase showed maximum stability at $\mathrm{pH}$ 8. Under the $\mathrm{pH} 5$ the lipase lost about $40 \%$ of its activity after holding at $4 \mathrm{hrs}$. The stability range was 7 to 9. Similar results were observed by Matsumae and Shibatani (1994). Serratia marcoscens Sr41 8000 lipase was stable between pH 6 to 9, also that of Serratia grimisii was stable over the $\mathrm{pH}$ range of 7 to 9 (Abdou, 1997). Other lipase showed stability with in the pH range of 5.5 to 9 (Fox and Stepaniak, 1983; Kumura et al., 1993).

\subsubsection{Optimum $\mathrm{pH}$}

The optimum $\mathrm{pH}$ was likely between 7 and 8 . The $\mathrm{pH}$ activity curve (Fig 1) showed that the enzyme reached about $100 \%$ of its maximum activity at $\mathrm{pH}$ 8. Abdou (1997) reported that the purified lipase from Serratia grimisii exhibited an optimum $\mathrm{pH}$ over the range 8 to 9, while that from $S$. marcescens $\mathrm{Sr} 418000$ showed maximum activity at about $\mathrm{pH}$ 8 (Matsumae and Shibatani, 1994). Previous investigation (Fox and Stepaniak, 1983) showed that the optimum $\mathrm{pH}$ for lipases from different psychrotrophs was 8 .

\subsubsection{Thermal Stability}

The lipase of $V$. fischeri showed $80 \%$ stability at $35^{\circ} \mathrm{C}$, but the least residual activities was at 5,10 and $50^{\circ} \mathrm{C}$. No activity was observed in $60,65^{\circ} \mathrm{C}$ and above. Petersen and Daniel (2006) determined the effects of temperature and $\mathrm{pH}$ on the activity of purified lipase was $6-9.5$ and $15-60^{\circ} \mathrm{C}$ respectively. The maximal activity was recorded at $40^{\circ} \mathrm{C}$ and at $\mathrm{pH} 8$.

\subsubsection{Optimum Temperature}

The effect of temperature on the lipase activity (Fig 2) showed that optimum temperature for the enzyme activity occurred at $30^{\circ} \mathrm{C}$ and about $80 \%$ of its maximum activity occurred at $5^{\circ} \mathrm{C}$. This high activity at low temperature was observed by some workers. Fox and Stepaniak (1983) found that purified lipase of P. fluorescens strain AFT 36 exhibited about $15 \%$ of its maximum activity at $4^{\circ} \mathrm{C}$, Stepaniak et al., (1987) reported that P. fluorescens P1 lipase showed about $30 \%$ at $4^{\circ} \mathrm{C}$.

\subsubsection{Enzyme and Substrate Kinetics}

The lipase activity was reached at maximum in between the 1 to $2 \mathrm{mM}$ tributyrin concentration. The $50 \%$ of the activity was inhibited by $7 \mathrm{mM}$ of tributyrin. This results was supported by Abdou (2003), he reported that the enzyme was inhibited by a concentration more than $6.25 \mathrm{mM}$. A linear relationship was also evident when enzyme activity was measured as a function of protein concentration. The same direct proportionality was found when crude extract were used as the source of enzyme (Oterholm et al., 1970).

\subsubsection{Effect of Metal Ions, Chelator and Other Chemicals on Lipase}

Figure 3 shows the results on the effect of various inhibitors on the activity of the lipase. Except $\mathrm{NaCl}_{1} \mathrm{CaCl}_{2}$, which were showed no effect on enzyme activity. All other ions tested in the present study showed inhibition with relative degree of variation. Evidently even the low concentration of $\mathrm{NAF}$ and $\mathrm{CuO}_{2}$ highly retarded the lipase activity. The ion chelator, EDTA and anionic detergent SDS, retarded lipase activity. The inhibitory action of former was stronger than that of latter. Action of these two compounds could be attributed to their effect in creating the imbalance of ions in the reaction mixture by absorption or release, respectively. Benjamin and Pandey (2000) reported that the chelator, EDTA and anionic detergent SDS effect $75 \%$ of lipase activity and the effect of EDTA is higher than the latter. In this study $80 \%$ of activity inhibited by SDS and no lipase activity was observed in the presence of EDTA.

\subsubsection{Enzyme Stability During Storage}

Figure 4 shows the lipase activity in the time of storage at different temperatures. Frozen storage did not affect the enzyme activity to any greater extent. The lipase enzyme stability suggests that the differences are due to a real decrease in enzyme production, rather than to an accelerated destruction of enzyme at higher temperatures. An explanation might be that the enzyme systems involved in lipase formation are repressed at higher temperatures, thus resulting in a lower productivity (Andersson, 1980).

\section{Conclusions}

$V$. fischeri is the bioluminous bacteria secreting extracellular lipase has been purified and characterized. The lipase hydrolytic activity upon tributyrin (C4) was found to be higher than upon triolein (C16). This higher effect of lipase was due to the different chain length of substrates. The characteristics such as $\mathrm{pH}$ stability in the alkaline range and high hydrolytic reaction on tweens and triacylglycerols will be useful for further research. Further study will focus on cloning and molecular characterization of the $V$. fischeri lipase coding gene. 


\section{References}

Abdou, A. M. (1997). Studies on some gram negative proteolytic and lipolytic microorganisms in milk and milk product. Ph.D., Diss., Zagazig Univ. (Benha branch), Kaliobyia. Egypt.

Abdou, A. M. (2003). Purification and partial characterization of psychrotrophic Serratia marcescens lipase. J. Dairy Sci, 86: 127-132.

Andersson, R. E. (1980). Microbial lipolysis at low temperature. App. Env. Microbiol, 39: 36-40.

Benjamin, S. \& Pandey, A. (2000). Isolation and characterization of three distinct forms of lipases from Candida rugosa produced in solid state fermentation. Brazilian Archives of Biology and Technology, 43: 453-460.

Bozoglu, F. (1984). Isolation and characterization of an extracellular heat-stable lipase produced by Pseudomonas flurescens. Agric. Food. Chem., 32: 2-6.

Bruni,V., Maugeri,T \& Alonzo, V. (1982). Lipolytic activity of marine bacteria influence of $\mathrm{NaCl}$ and $\mathrm{MgCl}_{2}$. Marine Biology, 67:113-119.

Fox, P. F. \& Stepaniak, L. (1983). Isolation and some properties of extracellular heat- stable lipases from Pseudomonas flurescens. Strain APT. 36. J. Dairy Res., 50: 77-89.

Ghanem, E. H., Al-Sayeed, H. A. \& Saleh, K. M. (2000). An alkalophilic thermostable lipase produced by new isolate of Bacillus alcalophilus. World Journal of Microbiology and Biotechnology, 16: 459-464.

Gupta, R., Gupta, N. \& Rathi, P. (2004). Bacterial lipases: an overview of production, purification and biochemical properties. Appl. Microbiol. Biotechnol. 64: 763-781.

Harris, L., Owens, L. \& Smith, S. (1996). A selective and differential medium for Vibrio harveyi. Appl. Environ. Microbiol, 62(9): 3548-3550.

Hendrie, M. S., Hodgkiss, W. \& Shewan, J. M. (1970). The identification, taxonomy and classification of luminous bacteria. J. Gen. Microbiol, 64: 151-169.

Jaeger, K. E. \& Reetz, M. T. (1998). Microbial lipases form versatile tools for biotechnology. Trends in Biotechno, 16: 396-403.

Jaeger, K. E., Dijkstra, B. W. \& Reetz, M. T. (1999). Bacterial biocatalysts: molecular biology, three-dimensional structure and biotechnological applications of lipases. Ann. Rev. Microbiol. 53: 315-35.

Jaeger, K. E., Ransac, S. Dijkstra, B. W. Colson, C. Van Henvel. \& Misset M. O. (1994). Bacterial lipases. FEMS Microbiol. Rev. 15: 29-63.

Kouker, G. \& Jaeger, K. E. (1987). Specific and sensitive plate assay for bacterial lipases. App. Environ. Microbiol, 53: 211-213.

Kumura, H., Mikawa, K. \& Sceito, Z. (1993). Purification and characterization of lipase from Pseudomonas fluorescens. Milchwissenschaft, 48:431-434.

Lee, K. H. \& Ruby, E. G. (1994). Effect of squid host on the abundance and distribution of symbiotic $V$. fischeri in nature. App. Environ. Microbiolog. 60. 1565-1571.

Lesuisse, E., Schanck, K. \& Colson, C. (1993). Purification and preliminary characterization of the extracellular lipase of Bacillus subtilis 168, an extremely basic pH tolerant enzyme. Eur. J. Biochem. 216:155-160.

Makhzoum, A., Knapp, J. S. \& Ownsce, R. K. (1995). Factors affecting growth and extracellular lipase production by Pseudomonas fluorescens. 2D. Food Microbiol, 12: 277-299.

Matsumae, H. \& Shibatani, T. (1994). Purification and characterization of lipase from Serratia marcescens Sr41 8000 responsible for asymmetric hydrolysis of 3- phenylglycidic acid esters. J. Ferment. Bioeng, 77:152-158.

Nawani, N. \& Kaur, J. (2000). Purification, characterization and thermostability of lipase from a thermophilic Bacillus sp. Molecular and Cellular Biochemistry, 206: 91-96.

Oterholm, A., Ordal. Z. J. \& Witter, L. D. (1970). Purification and properties of a glycerol ester hydrolase (lipase) from Propionibacterium shermanii. App. Microbiol. 20:16-22.

Petersen, M. \& Daniel, R. (2006). Purification and characterization of an extracellular lipase from Clostrium tetanomorphum. World Journal of Microbiology and Biotech. 22:431-35.

Reichelt, J. L. \& Baumann, P. (1973). Taxonomy of the marine, luminous bacteria. Arch. Microbiol. 94: 283-330.

Ruby, E. G. \& Nagai, M. J. M. (1992). A squid that glows in the night: development of an animal bacterial animal mutualism. J. Bacteriol, 174: 4865-4870. 
Ruby, E. G. \& Nealson, K. H. (1976). Symbiotic association of Photobacterium fischeri with the marine luminous fish Monocentris japonica: a model of symbiosis based on bacterial studies. Biol. Bull. 151: 574-586.

Sabu, A. (2003). Sources, properties and applications of microbial therapeutic enzymes. Indian J. Biotechnol. 2: 334-341.

Schmidt-Dannert. C., Sztajer, H., Stocklein, S., Menge, V. \& Schmid, K. D. (1994). Screening, purification and properties of a thermophilic lipase from Bacillus thermocatenulatus. Biochem. Biophys. Acta, 1214:1249-1259.

Shabtai, Y. \& Mishne, N.D. (1992). Production, purification and properties of lipase from a bacterium (Pseudomonas aeruginosa YS-7) capable of growing in water-restricted environments. App. Environ. Microbial, 59:174-180.

Stepaniak, L., Brikeland, J.E., Sorhavy, T. \& Vagias, G. (1987). Isolation and partial characterization of heat stable proteinase, lipase and phospholipase C from Pseudomonas fluorescence. Milchwissenschaft. 12: 75-79.

Stepaniak, L., and Fox, P. F. (1985). Isolation and characterization of heat stable proteineases from Pseudomonas fluorescens strain AFT 21. J. Dairy Res., 52: 77-89.

Vorderwulbecke, T., Kieslich, K. \& Erdman, H. (1992). Comparison of lipases by different assays. Enzyme Microb. Technol, 14: 631-639.

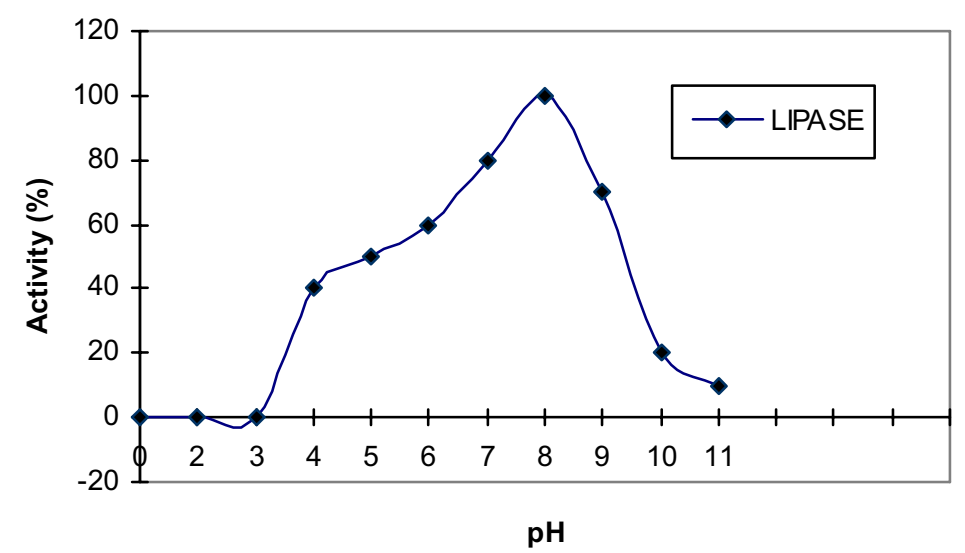

Figure 1. Effect of $\mathrm{pH}$ on the Lipase Enzyme from Vibrio fischeri

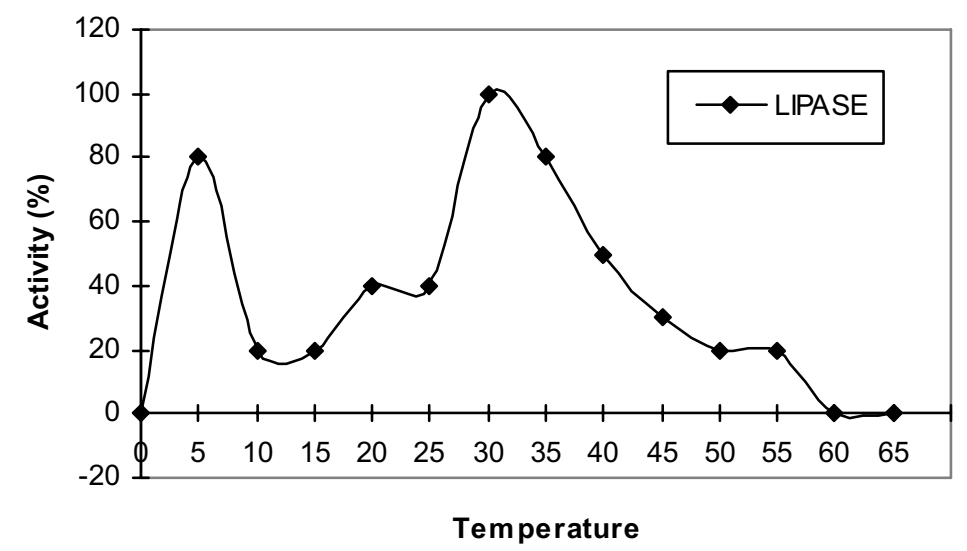

Figure 2. Effect of Temperature on the Lipase Enzyme from Vibrio fischeri 


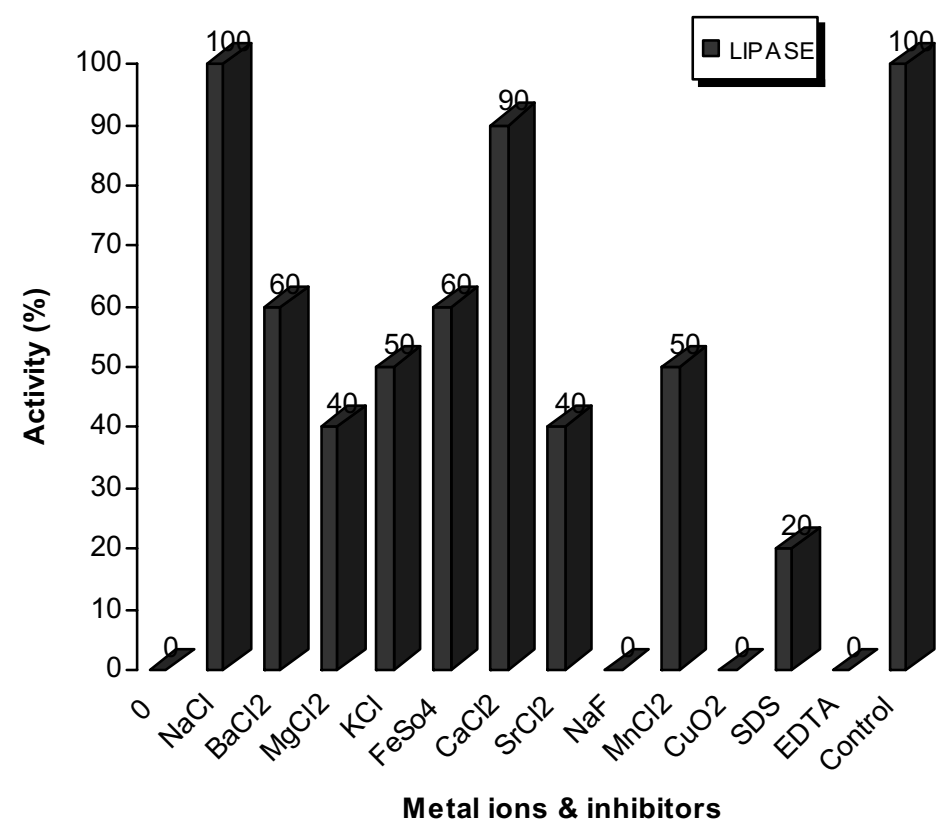

Figure 3. Effect of inhibitors on lipase enzyme

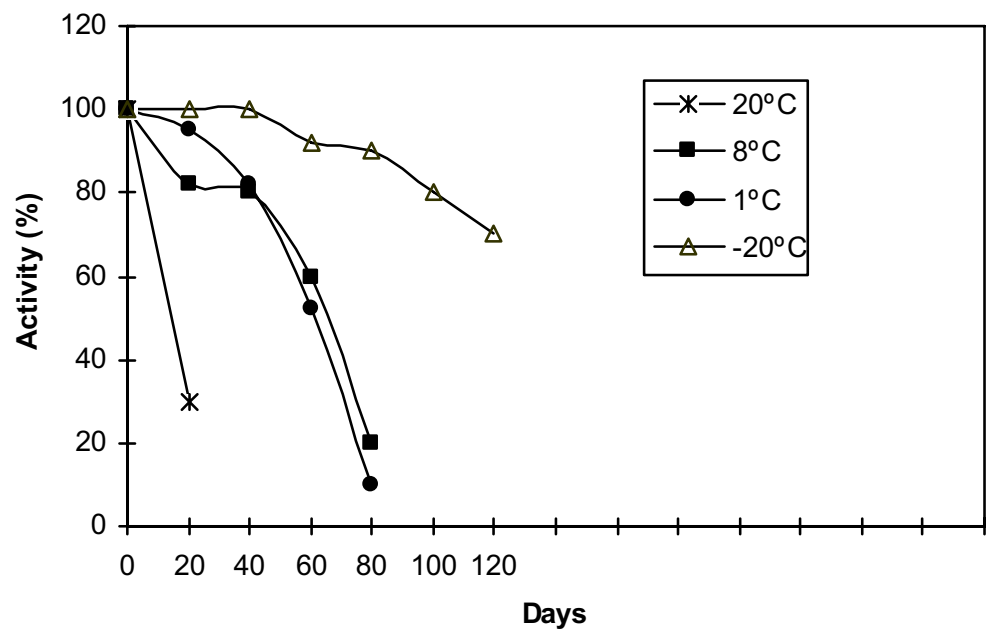

Figure 4. Storage Stability of Vibrio fischeri Lipase at Different Temperature 


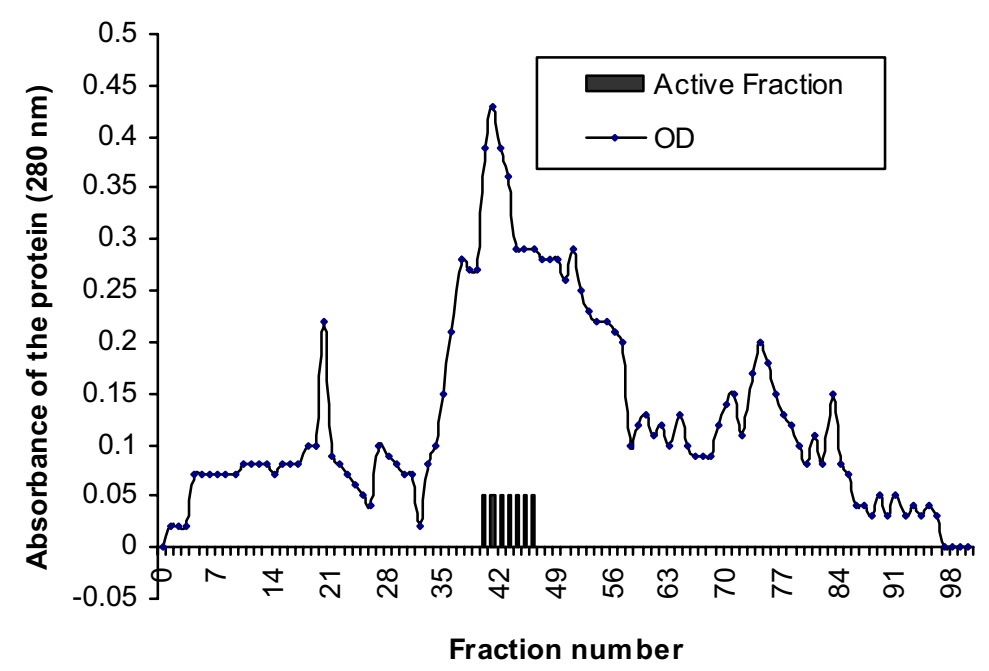

Figure 5. Elution Profile of Lipase from the DEAE-Cellulose Column

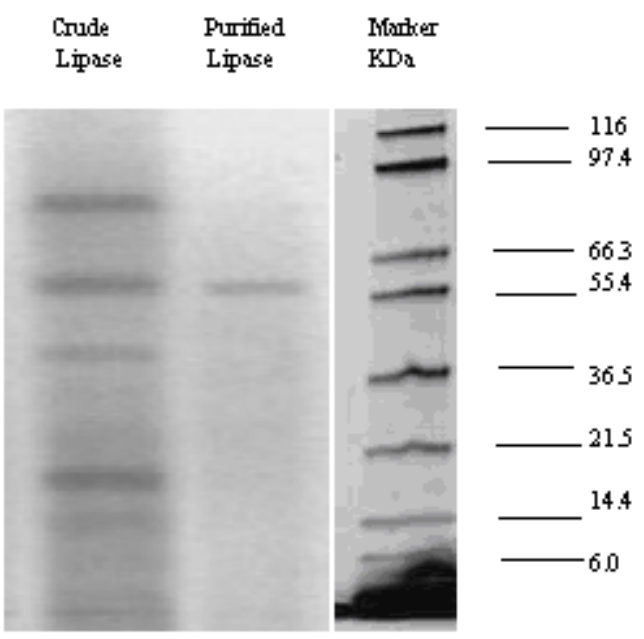

Figure 6. Molecular Mass of Crude and Purified V. fischeri Lipase 